\title{
Effect of flow rate on the performance of Biosand Filter
}

\author{
Amenan Lydie Clarisse MANGOUA-ALLALI ${ }^{1 *}$ and Lacina COULIBALY ${ }^{1,2}$ \\ ${ }^{1}$ Unité de Formation et de Recherche en Sciences et Gestion de l'Environnement, Université Nangui Abrogoua, \\ 02 BP 801, Abidjan 02, Côte d'Ivoire. \\ ${ }^{2}$ Département de Géologie et Matériaux, Université de Man, BPV 40, Man, Côte d'Ivoire. \\ ${ }^{*}$ Corresponding author; E-mail: amelydi@yahoo.fr ; Tel. +2250778849446
}

\begin{tabular}{ccc}
\hline Received: 17-04-2021 & Accepted: 28-09-2021 & Published: 30-10-2021 \\
\hline
\end{tabular}

\begin{abstract}
Lack of access to safe drinking water is an issue in some areas where centralized water treatment is not possible, the biosand filter (BSF) one of several such point-of-use technologies is available. This study was conducted in Côte d'Ivoire to evaluate the effect of flow rate on the performance of the BSF. Three biosand filter (BSF) built in Poly vinyl chloride was used to investigate the effect of three flow rates $(1.95 \mathrm{~L} / \mathrm{d}$ in BSF1; 3.9 L/d in BSF2 and 7.8 L/d in BSF3) for 91 days. Each BSF was filled with $15 \mathrm{~cm}$ of gravel, $90 \mathrm{~cm}$ of sand and 40 $\mathrm{cm}$ of supernatant water. Physical and chemical parameters were analyzed in raw water and filtered water with standards methods. The results showed that the percentage removal of TSS approximately the same for all filters. Ammonium concentrations ranged from 37 to $170 \mu \mathrm{g} . \mathrm{L}^{-1}, 110$ to $190 \mu \mathrm{g} . \mathrm{L}^{-1}$ and 150 to $278 \mu \mathrm{g} . \mathrm{L}^{-1}$ for filtered waters of BSF1, BSF2 and BSF3, respectively. Nitrite concentrations in filtered waters of BSF1 (2 - $\left.33 \mu \mathrm{g} . \mathrm{L}^{-1}\right)$ were less than those of BSF2 (5 - $\left.45 \mu \mathrm{g} . \mathrm{L}^{-1}\right)$ and BSF3 $\left(7-49.5 \mu \mathrm{g} . \mathrm{L}^{-1}\right)$. Nitrate concentrations in filtered waters of BSF2 (1.9 to $4 \mathrm{mg} . \mathrm{L}^{-1}$ ) and BSF3 (1.6 to $\left.4.2 \mathrm{mg} . \mathrm{L}^{-1}\right)$ were higher than those of BSF1 (0.6 to $\left.2.3 \mathrm{mg} . \mathrm{L}^{-1}\right)$. Chemical Oxygen Demand removal efficiency for BSF3 $(68.2 \pm 9.5 \%)$ was lower compared to BSF2 $(82.6 \pm$ $3.8 \%)$ and BSF1 $(93.7 \pm 2.8 \%)$. The flow rate has an influence only on the removal of ammonium, nitrite, nitrate and Chemical Oxygen Demand. The best treatment results were obtained with the minimum flow rate $(1.95 \mathrm{~L} / \mathrm{d})$. (C) 2021 International Formulae Group. All rights reserved.
\end{abstract}

Keywords: Biosand filters, flow rate, physicochemical parameters, raw water, filtered water, Côte d'Ivoire.

\section{INTRODUCTION}

The increase in the consumption of water in the developing world is directly related to the rapid growth of populations (Bied-Charreton et al., 2004). This situation is unfortunately not without consequences. Indeed, many people, particularly, who live in rural and slum areas do not have access to drinking water (WHO, 2004). This lack of access places significant health and economic burdens on people (Aiken et al., 2011). In these settings children under and pregnant ladies are the most vulnerable to diarrhoea and other waterborne diseases (Chaudhary et al., 2019).

In developing countries provision of water in urban areas use centralized treatment. This conventional treatment makes governments are often plagued by high capital costs in urban water supply (UNESCO, 2004). Despite these investments, the centralized water treatment (coagulation-flocculation, air stripping, ion exchange resins...) have proved 
to be unsuitable due to the lack of proper operation and maintenance (Hamouda et al., 2008).

In rural and semi-rural areas, water infrastructures are either poorly developed or non-existent (Varbanets et al., 2009). So, most of communities collect their water from river, groundwater or ponds (Arnal et al., 2010). These water resources are often faecally, microbiologically or chemically contaminated and not treated before utilisation (Hounsounou et al., 2016).

Cases of pollution of drinking water have been observed in different areas of developing countries, for example those of Yamtenga in Burkina Faso (Ayouba Mahamane and Guel, 2015), Sèmè-Podji in Benin (Dovonou et al., 2017) and Kpangouin in Man in Côte d'Ivoire (Ahoussi et al., 2018).

In view of the above, it is possible to say that the centralized systems are deficient in developing countries. But a range of decentralized systems is available to counter these problems. The decentralized systems that treat the potable water include point-of-use systems. Point-of-use water treatment technologies are feasible technique to produce drinkable water in developing country (Cadmus Group, 2006; Kayaga et Reed, 2009). Among the most common point-of-use water treatment options, the biosand filter have showed great potential to reduce physical and microbial contamination in water (Hamidon et al., 2020). For example, the removal percentages for E. coli, turbidity, and iron are 99.7, 98 and $71 \%$ respectively (Baker and Duke, 2006; Elliott et al., 2006). The biosand filter is built using materials that are available everywhere (Hamidon et al., 2020). Despite these advantages, few studies have been carried out on biosand filtration as a water treatment method in African countries, particularly in Côte d'Ivoire where the difficulty of access to water is also real. In these settings, that the present study proposes to develop a biosand filter based on one the design parameters: flow rate. Especially, the study was to examine the effect of flow rate on the removal of ammonium, nitrite, nitrate, Chemical Oxygen
Demand and Total Suspended Solid in a biosand filter.

\section{MATERIALS AND METHODS Biosand column setup}

A cross-sectional diagram of the reactors is shown in Figure 1. Three biosand filter (BSF) were constructed with Poly Vinyl Chloride (PVC) with a diameter of $11 \mathrm{~cm}$. The BSF had a total length of $170 \mathrm{~cm}$. Each BSF was filled with $15 \mathrm{~cm}$ of underdrain gravel $(15 / 20 \mathrm{~mm}), 90 \mathrm{~cm}$ of sand and $40 \mathrm{~cm}$ of supernatant water. Sand was obtained from a local lagoon. Sand was sieved, washed and dried. The BSF used sand with an effective size of $0.95 \mathrm{~mm}$ and a uniformity coefficient of 0.41 .

\section{Sand column operation}

Three columns were operated in parallel and designed to operate in batch mode (intermittent flow). Flow rate of $1.95 \mathrm{~L} / \mathrm{d} ; 3.9$ $\mathrm{L} / \mathrm{d}$ and $7.8 \mathrm{~L} / \mathrm{d}$ of water were added to BSF1, BSF2 and BSF3 respectively, from Monday to Friday for 91 days. Raw water (RW) was collected once per week from river Banco (Abidjan, Côte d'Ivoire).

\section{Analysis}

The analytical methods used to analyse the water quality were in accordance with standard methods (AFNOR, 2005). Once per week, raw water and filtered water were analyzed with Hach DR2010 spectrophotometer for ammonium $\left(\mathrm{NH}_{4}{ }^{+}\right)$ (distillation-nesslerization method), nitrite $\left(\mathrm{NO}_{2}{ }^{-}\right)$(Diazotization Method), nitrate $\left(\mathrm{NO}_{3}{ }^{+}\right)$ (cadmium reduction), and Chemical Oxygen Demand (COD) (Potassium dichromate oxidation method). Total Suspended Solid (TSS) was measured by filter method. $\mathrm{pH}$ was determined with a multi parameter (Model C830 consort).

Flow rate was also measured to assess for clogging. Raw water was collected from the river. Filtered water has been collected from the tube after raw water was charged to the BSF.

The percentages of filter clogging were calculated from the average water flow rates 
before and after the experiment according to the equation 1.

$\mathrm{C}(\%)=\frac{v_{1}-v_{2}}{v_{1}} \times 100 \quad$ equation 1

With:

$\mathrm{C}=$ Percentage of clogging $(\%)$;

$v_{1}=$ Mean water flow rate before experiment $\left(\mathrm{mL} . \mathrm{s}^{-1}\right)$;

$v_{2}=$ Mean water flow rate after experiment $\left(\mathrm{mL} \cdot \mathrm{s}^{-1}\right)$.

The Hydraulic Retention Time (HRT) represents the average time it takes for a drop of water to pass from the inlet to the outlet of the BSF. It was determined by the equation 2 .

$\mathrm{HRT}=\frac{\mathrm{V}_{\mathrm{f}}}{\mathrm{Q}}=\frac{\Pi \mathrm{D}^{2}(\mathrm{~h}+\mathrm{l})}{4 \mathrm{Q}}$ equation 2

With:

HRT $=$ Hydraulic retention time;

$\mathrm{Q}=$ Water infiltration flow rate into the filter $\left(\mathrm{dm}^{3} /\right.$ day $)$;

$\mathrm{V}_{\mathrm{f}}=$ Filter volume $\left(\mathrm{dm}^{3}\right)$;

$\mathrm{D}=$ Diameter at filter inlet $(\mathrm{dm})$; $\mathrm{h}=$ Sand height in the filter $(\mathrm{dm})$;

$\mathrm{l}=$ Supernatant water in the filter $(\mathrm{dm})$.

The removal efficiency $(\mathrm{R})$ of the BSF were calculated from the equation 3 .

$\mathrm{R}(\%)=\frac{\mathrm{C}_{0}-\mathrm{C}}{\mathrm{C}_{0}} \times 100 \quad$ equation 3

With:

$\mathrm{R}=$ Removal efficiency of the BSF (\%);

$\mathrm{C}_{0}=$ Concentration of the parameter considered in the raw sample (mg.L $\left.\mathrm{L}^{-1}\right)$;

$\mathrm{C}=$ Concentration of the parameter considered in the filtrate $\left(\mathrm{mg} \cdot \mathrm{L}^{-1}\right)$.

\section{Statistical analyses}

To compare the averages of more than two groups, the nonparametric Kruskal-Wallis test was used because data don't respect the normal law. After that, the post hoc multiple comparison test of mean ranks (bilateral) has been used to see if data were significant. These statistical tests were performed using STATISTICA 7.1 software (Statsoft, 2005), with a significance level of $5 \%$.

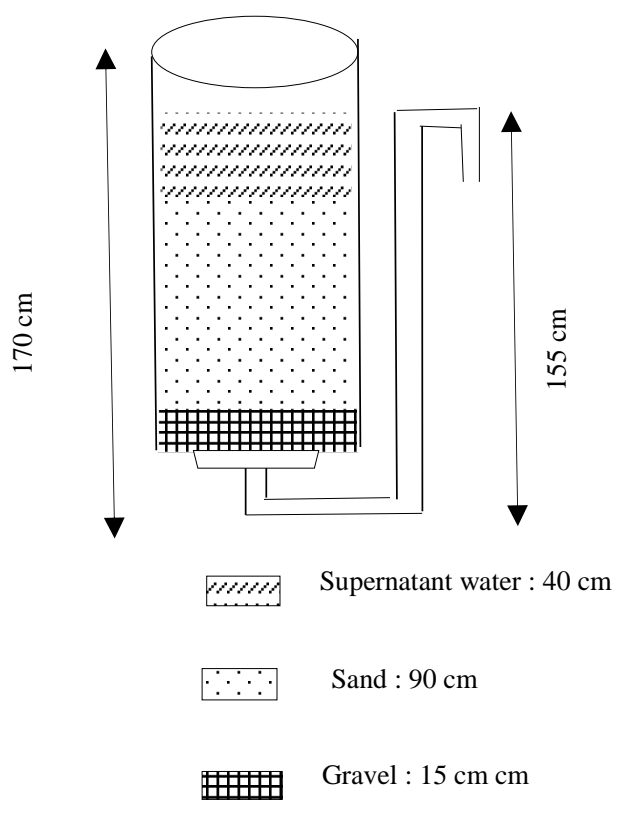

Figure 1: Cross-sectional diagram of the biosand filter technology. 


\section{RESULTS}

\section{Physicochemical parameters \\ pH}

The Raw water $\mathrm{pH}$ was found to be between 5.4 and 6.08 (Figure 2). Filtered water of BSF1, BSF2 and BSF3 was varied respectively from 6.44 to $7.49,6.3$ to 6.95 , and 6.15 to 6.86 (Figure 2). The Kruskal-Wallis test showed differences between the RW pH and the filtered water $(\mathrm{p}<0.05)$. This difference was only significant between RW and filtered waters of (BSF1 and BSF2) (multiple comparison test of mean ranks: $\mathrm{p}<0.05)$. Filtered water $\mathrm{pH}$ did not have a statistically significant from one filter to another (multiple comparison test of mean ranks: $p>0.05$ ). However, the $\mathrm{pH}$ in filtered water of BSF1 was higher than that of BSF2 and BSF3.

$\mathrm{NH}_{4}{ }^{+}$

A comparison of RW and filtered water for $\mathrm{NH}_{4}{ }^{+}$concentrations are shown in Figure 3. $\mathrm{NH}_{4}{ }^{+}$concentrations of $\mathrm{RW}$ ranged from 212 to $320 \mu \mathrm{g} . \mathrm{L}^{-1}$ over the course of the experiment. Overall, $\mathrm{NH}_{4}{ }^{+}$concentrations of filtered water were 37 to $170 \mu \mathrm{g} . \mathrm{L}^{-1}, 110$ to $190 \mu \mathrm{g} . \mathrm{L}^{-1}$ and 150 to $278 \mu \mathrm{g} . \mathrm{L}^{-1}$ for BSF1, BSF2 and BSF3, respectively. The multiple comparison test of mean ranks confirmed significant differences in $\mathrm{NH}_{4}{ }^{+}$concentrations between $\mathrm{RW}$ and filtered waters (BSF1 and BSF2), between filtered water of BSF1 and BSF3 ( $p<0.05)$. The highest removal occurred in the BSF1 (71.2 $\pm 17.4 \%$ ), while the BSF3 achieved the lowest removal $(20.4 \pm 7.3 \%) . \mathrm{NH}_{4}{ }^{+}$also showed reduction in BSF2 with a reduction of $42.4 \pm 8.6 \%$.

$\mathrm{NO}_{2}^{-}$

$\mathrm{NO}_{2}^{-}$concentrations of filtered waters of BSF1 (2-33 $\left.\mu \mathrm{g} . \mathrm{L}^{-1}\right)$, BSF2 (5-45 $\left.\mu \mathrm{g} . \mathrm{L}^{-1}\right)$ and
BSF3 (7-49.5 $\left.\mu \mathrm{g} . \mathrm{L}^{-1}\right)$ were higher than RW concentration (3-23 $\mu \mathrm{g} . \mathrm{L}^{-1}$ ) (Figure 4). There was no statistical difference between the $\mathrm{NO}_{2}{ }^{-}$ concentrations of RW and filtered waters (Kruskal-Wallis test: $p>0.05$ ). It was noted that $\mathrm{NO}_{2}^{-}$concentrations in the filtered waters increased with the applied water flow. However, a significant statistically was not identified between $\mathrm{NO}_{2}^{-}$concentrations of filtered water $(\mathrm{p}>0.05)$.

$\mathrm{NO}_{3}^{-}$

$\mathrm{NO}_{3}-$ concentrations in the $\mathrm{RW}$ were lower than those in filtered waters of BSF2 and BSF3 (Figure 5). But they were higher than the $\mathrm{NO}_{3}{ }^{-}$concentrations filtered waters of BSF1. $\mathrm{NO}_{3}{ }^{-}$concentrations in the $\mathrm{RW}$ ranged from 0.4 to $2.5 \mathrm{mg} . \mathrm{L}^{-1}$. In contrast, in filtered waters, the ranges of variation were 0.6 to $2.3 \mathrm{mg} . \mathrm{L}^{-1}, 1.9$ to $4 \mathrm{mg} . \mathrm{L}^{-1}, 1.6$ to $4.2 \mathrm{mg} . \mathrm{L}^{-1}$ in filtered waters of $\mathrm{BSF} 1, \mathrm{BSF} 2$ and $\mathrm{BSF} 3$ respectively.

\section{TSS and COD}

Figure 6 shows the removal efficiency of TSS and COD in the biosand filters. TSS removal efficiency was $96.9 \pm 7.9 \%$ for BSF1, $97.6 \pm 5.1 \%$ for BSF2, $97.9 \pm 5.3 \%$ for BSF3. These percentages were substantially the same. The highest removal efficiency in COD were $93.7 \pm 2.8 \%$ and $82.6 \pm 3.8 \%$. This was obtained in the BSF1 (1.95 L/d) and BSF2 (3.9 L/d) respectively. The lowest COD removal efficiency $(68.2 \pm 9.5 \%)$ was obtained in the BSF3 (7.8 L/d).

\section{Clogging Characteristics}

The clogging percentages were 29.5; 50.6 and $67 \%$ respectively for BSF1, BSF2 and BSF3. These percentages of clogging increased with the flow rate. 


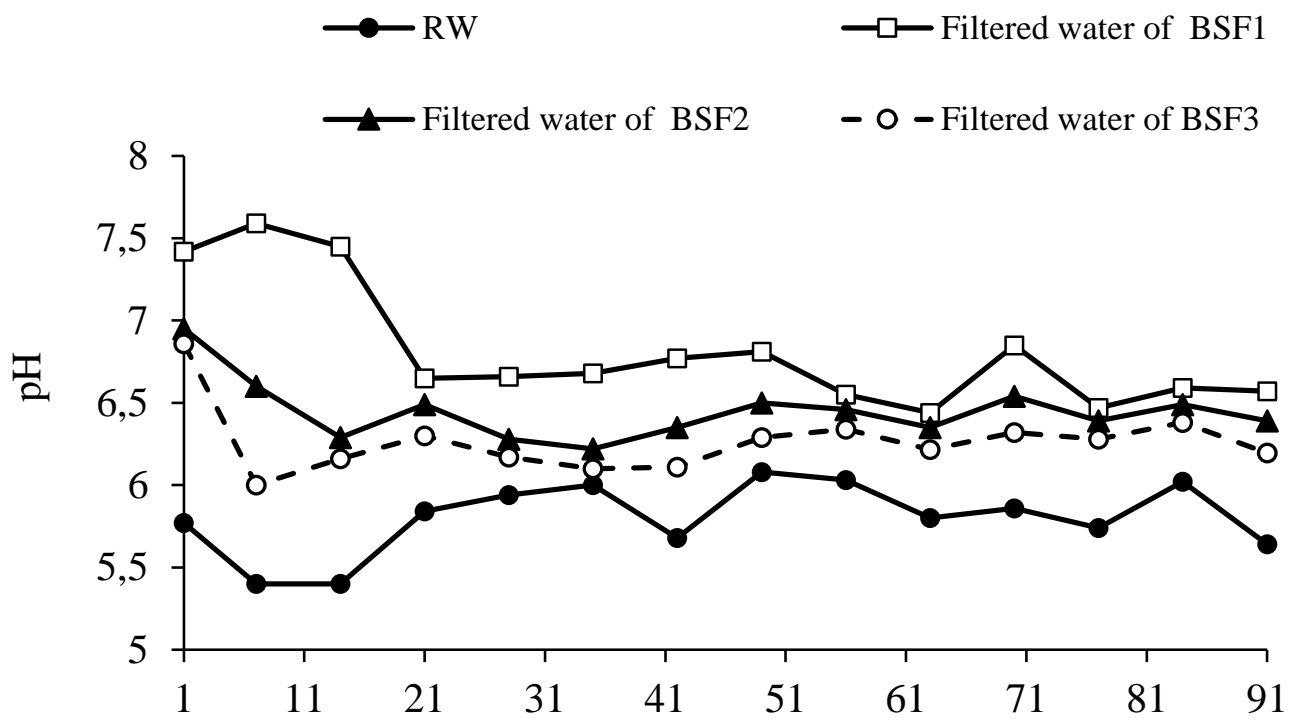

Days (d)

Figure 2: $\mathrm{pH}$ profiles of raw water (RW) and filtered waters for 91 days.

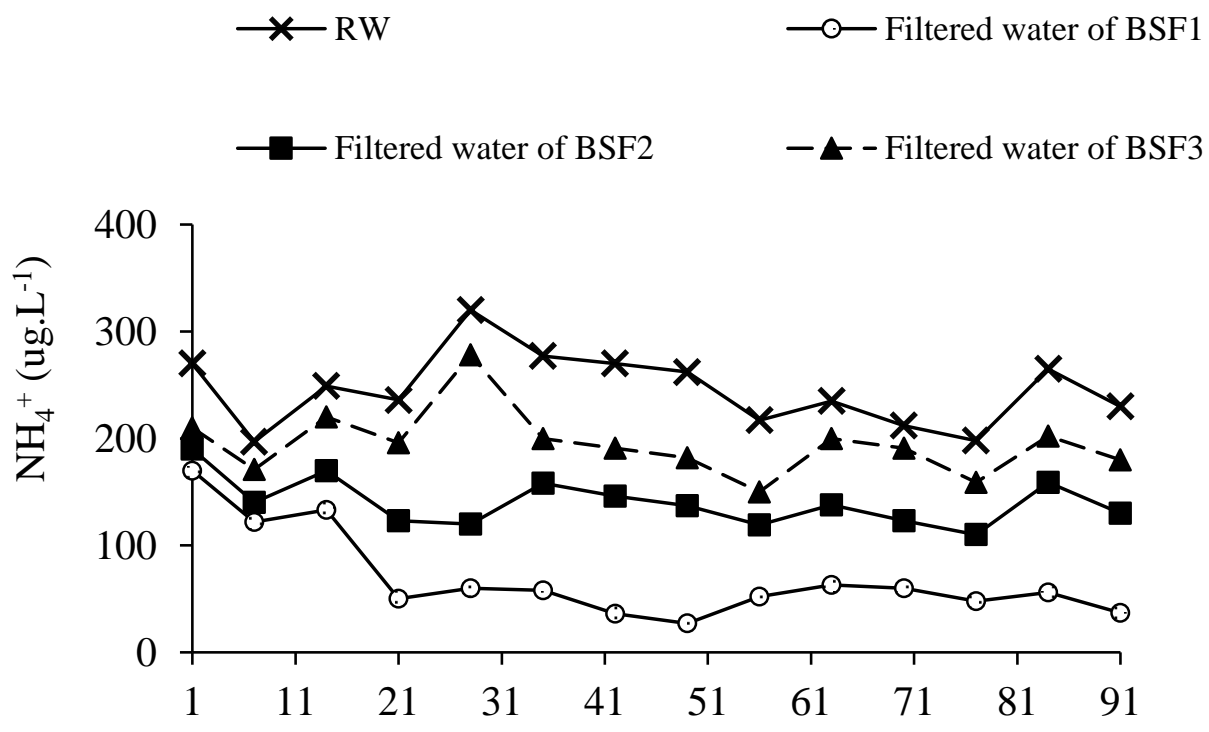

Days (d)

Figure 3: Raw water (RW) and filtered water for $\mathrm{NH}_{4}{ }^{+}$concentrations for 91 days. 


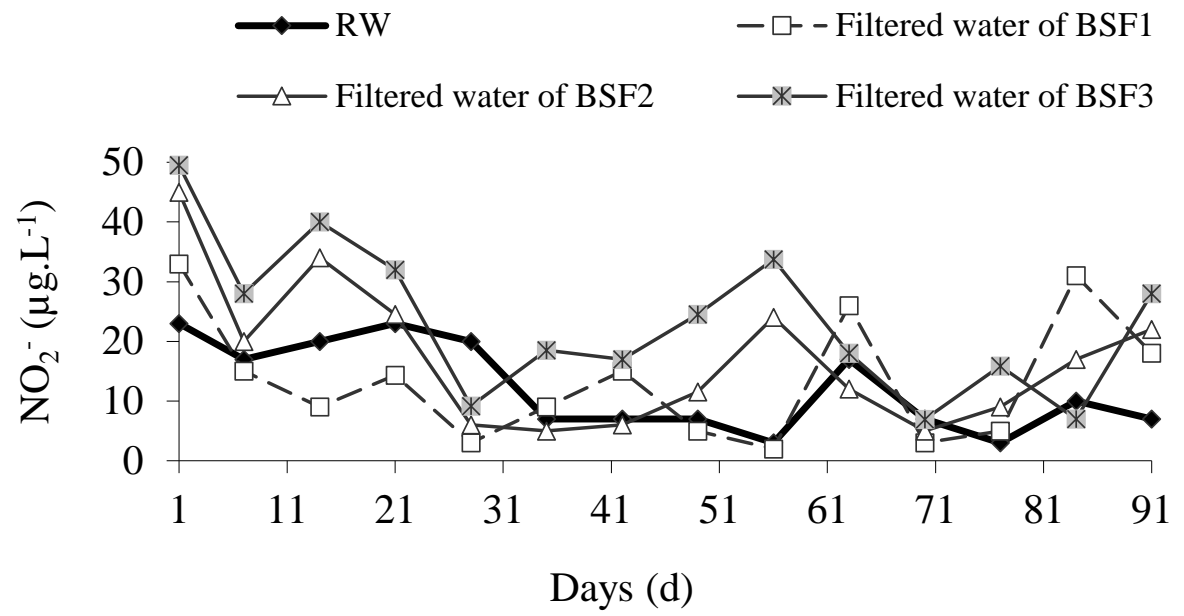

Figure 4: Raw water (RW) and filtered water for $\mathrm{NO}_{2}^{-}$concentrations for 91 days.

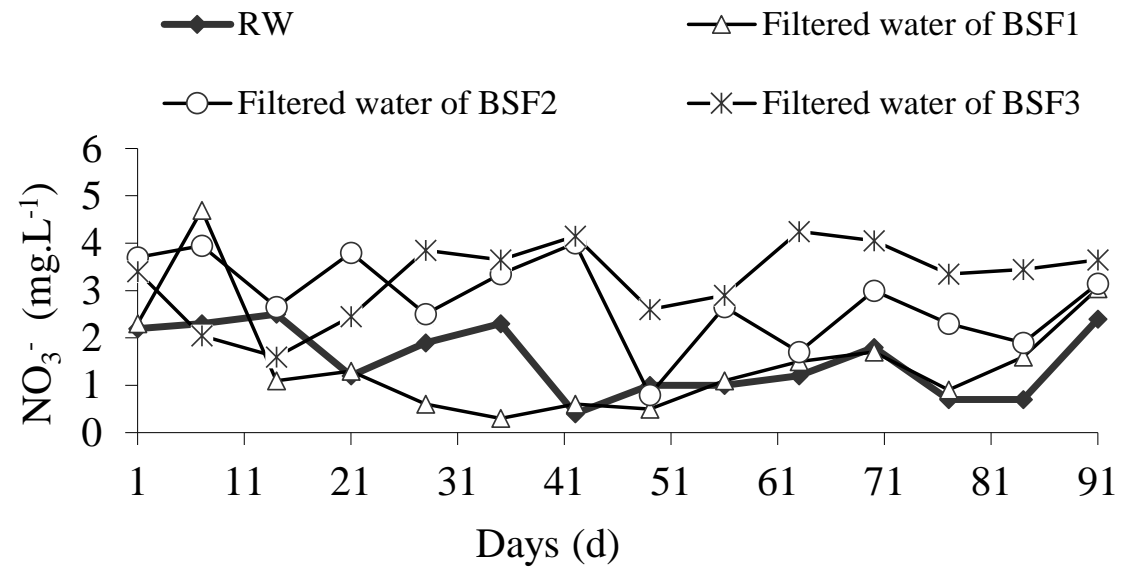

Figure 5: Raw water (RW) and filtered water for $\mathrm{NO}_{3}{ }^{+}$concentrations for 91 days.

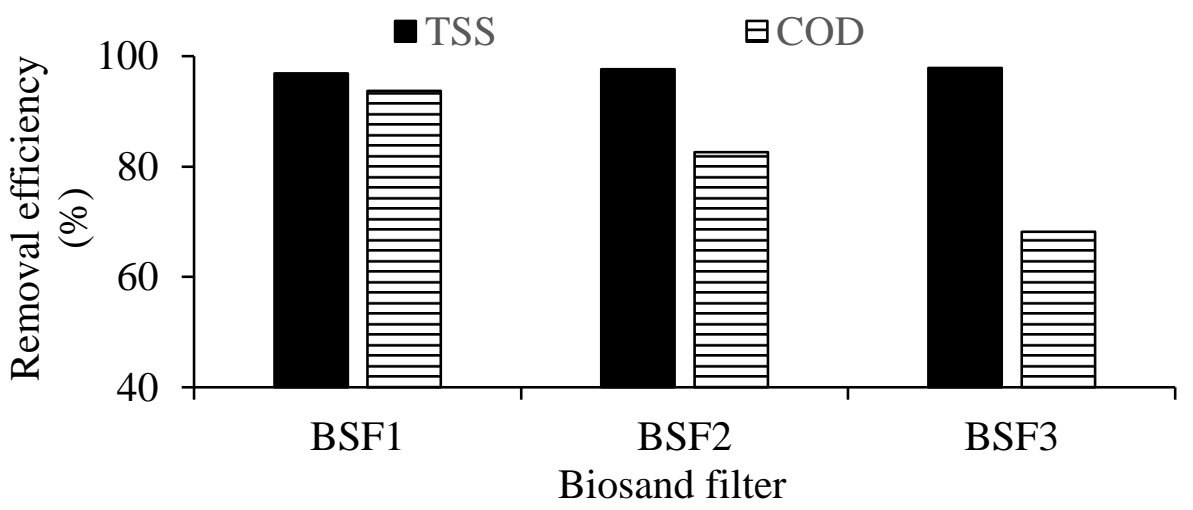

Figure 6: TSS and COD removal efficiency in biosand filters. 


\section{DISCUSSION}

$\mathrm{pH}$ evolved to acidic values when the flow rate increased from $1.95 \mathrm{~L} / \mathrm{d}$ to $7.8 \mathrm{~L} / \mathrm{d}$. This difference could be explained by a decrease in the aeration of the bed media due to the increase of the flow rate, which would reduce nitrification and oxidation of organic matter, resulting in acid $\mathrm{pH}$ (Neyman and Bray, 2000; Strauss et al., 2002). Our result is not similar to that reported by Ahammed and Davra (2011) who did not obtain a significant difference between the $\mathrm{pH}$ of the raw water and the filtered despite the increase of flow rate from $20 \mathrm{~L} / \mathrm{d}$ to $40 \mathrm{~L} / \mathrm{d}$ on two biosand filters, one of which was modified by adding $10 \mathrm{~cm}$ of iron oxide-rich sand. Only filtered water from BSF supplied with $1.95 \mathrm{~L} / \mathrm{d}$ and $3.9 \mathrm{~L} / \mathrm{d}$ respect WHO standards (WHO, 2008).

Results of $\mathrm{NH}_{4}^{+}, \quad \mathrm{NO}_{2}^{-}, \quad \mathrm{NO}_{3}{ }^{-}$ concentrations could be explained by the combined action of slowing down the oxygen transfer in the biosand filters and reducing the hydraulic residence time in biosand filters fed with $3.9 \mathrm{~L} / \mathrm{d}(\mathrm{HRT}=3 \mathrm{~d})$ and $7.8 \mathrm{~L} / \mathrm{d}(\mathrm{HRT}=1$ d) due to the increase of the flow rate (Kouakou, 2007; Gujer, 2010). This increase has resulted in a significant supply of particles that has clogged the biosand filters and therefore slowed down the transfer of oxygen by diffusion into the bed media. So, the activity of nitrifying bacteria is reduced (Zielińska and Wojnowska, 2007). This would explain the large output of $\mathrm{NH}_{4}{ }^{+}, \mathrm{NO}_{2}{ }^{-}, \mathrm{NO}_{3}{ }^{-}$in biosand filters supplied with $3.9 \mathrm{~L} / \mathrm{d}$ (BSF2) and $7.8 \mathrm{~L} / \mathrm{d}$ (BSF3) compared to the one supplied with 1.95 L/d (BSF1). These results are in agreement with the ones obtained by Langenbach (2009) who reported that high organic loads implied low nitrification. Regardless of the flow rate, the concentrations of $\mathrm{NH}_{4}{ }^{+}, \mathrm{NO}_{2}{ }^{-}, \mathrm{NO}_{3}{ }^{-}$in the different filtered water were below WHO standards (WHO, 2008).

TSS removal efficiency did not differ significantly from one biosand filter to another because the developed biosand filters had the same characteristics. Indeed, according to Healy et al. (2007), the elimination of TSS was carried out by mechanical filtration, which depends on the characteristics of sand.

The removal efficiency of COD decreases when the flow rate increases. This would be due to the limitation of microbial oxidation of organic matter (Tchobanoglous et al., 2003; Rolland et al., 2009). COD removal efficiency for BSF3 was lower than that (80 $90 \%$ ) obtained by slow sand filters (Cadmus Group, 2006). But for BSF2, the percentage of removal was in the above range. And for BSF1, the percentage was higher than this range.

The percentages of clogging increased with the flow rate. This may have been due to a significant contribution of pollutant loads from the increased of flow rate, which reduced the poral space in the sand (Wotton, 2002). Suspended particles get deposited either inside the filter matrix or on its surface (Viccione et al., 2018).

\section{Conclusion}

Water quality testing of biosand filter in the present study concluded that the flow rate has an influence on the performance of the filters. Indeed, the $\mathrm{pH}$ values increased as the flow rate decreased. The TSS removal is due to the height of the sand and not to the flow rate. $\mathrm{NH}_{4}{ }^{+}, \mathrm{NO}_{2}^{-}, \mathrm{NO}_{3}{ }^{-}$and COD concentrations in the filtered waters increased as the flow rate increase. The best treatment results were obtained with the minimum flow rate $(1.95$ L/d). As an additional step to evaluate the influence of flow rate on the biosand filter capability to remove fecal microorganisms will be do in future research.

\section{COMPETING INTERESTS}

The authors declare that they have no competing interests.

\section{AUTHORS' CONTRIBUTIONS}

Study design and planning were done by ALCMA and LC. Data acquisition, analysis, and interpretation by ALCMA. Manuscript writing by ALCMA and LC. 


\section{REFERENCES}

AFNOR. 2005. Qualité de l'Eau. AFNOR: Paris.

Ahammed MM, Davra K. 2011. Performance evaluation of biosand filter modified with iron oxide-coated sand for household treatment of drinking water. Desalination, 276: 287-293. DOI: 10.1016/j.desal.2011.03.065

Ahoussi KE, Keumean KN, Kouassi AM, Koffi YB. 2018. Étude des caractéristiques hydrogéochimiques et microbiologiques des eaux de consommation de la zone périurbaine de la ville de Man: cas du village de Kpangouin (Côte d'Ivoire). Int. J. Biol. Chem. Sci., 11(6): 3018-3033. DOI: https://dx.doi.org/10.4314/ijbcs.v11i6.37

Aiken BA, Stauber CE, Ortiz GM, Sobsey MD. 2011. An assessment of continued use and health impact of the concrete biosand filter in Bonao, Dominican Republic. Am. J. Trop. Med. Hyg., 85(2): 309-317. DOI: 10.4269/ajtmh.2011.090122

Arnal JM, Fayos BG, Sancho M, Verdú G, Lora J. 2010. Design and installation of a decentralized drinking water system based on ultrafiltration in Mozambique. Desalination, 250: 613-617. DOI: 10.1016/J.DESAL.2009.09.035

Ayouba Mahamane A, Guel B. 2015. Caractérisations physico-chimiques des eaux souterraines de la localité de Yamtenga (Burkina Faso). Int. J. Biol. Chem. Sci., 9(1): 517-533. DOI: http://dx.doi.org/10.4314/ijbcs.v9i1.44

Baker DL, Duke WF. 2006. Intermittent slow sand filters for household use: a field study in Haiti. In Recent Progress in Slow Sand and Alternative Biofiltration Processes, Gimbel IR, Graham JD, Collins MR (eds). IWA Publishing: London; 278-282.

Bied-Charreton M, Makkaoui R, Petit O, Requier-Desjardins M. 2004. La gouvernance des ressources en eau dans les pays en développement. Cahier $d u$ C3ED, 4(1): 1-43.

Cadmus Group. 2006. Point-of-use or point-ofentry treatment options for small drinking water systems. United States Environmental Protection Agency (USEPA), USA, $127 \mathrm{p}$. https://www.epa.gov/sites/production

Chaudhary P, Gopal L, Pant K, Pande A. 2019. Water borne diseases: life threatening impact on maternal health. Int. J. Eng. $A d v . \quad$ Technol., 8(4S): 6-11. DOI: 10.35940/ijeat.D1002.0484S19

Dovonou FE, Alassane A, Adjahossou VN, Agbodo B, Djibril R, Mama D. 2017. Impacts de l'assainissement autonome sur la qualité des eaux de puits dans la Commune de Sèmè-Podji (Sud-Bénin). Int. J. Biol. Chem. Sci., 11(6): 3086-3099. DOI: 10.4314/ijbcs.v11i6.42

Elliott MA, Stauber CE, Koksal F, Liang KR, Huslage DK, Digiano FA, Sobsey MD. 2006. The operation, flow conditions and microbial reductions of an intermittently operate, household scale slow sand filter. In Recent Process in Slow Sand and Alternative Biofiltration Processes, Gimbel IR, Graham JD, Collins MR (eds). IWA publishing: London; 268-277.

Gujer W. 2010. Nitrification and me-a subjective review. Water Res., 44(1): 119. DOI: $10.1016 /$ j.watres.2009.08.038

Hamouda MA, Anderson WB, Huck PM. 2008. Point-of-use/entry drinking water strategy for arab countries. In International Prize for Water (ed). ICWRAE-PSIPW: Riyadh-Kingdom of Saudi Arbia; 1-19.

Hamidon N, Yahya SH, Sunar NM, Muhamad MS, Harun H, Hamid AH, Ali R. 2020. Surface water treatment by using biosand filter and Hibiscus Rosa Sinensis leaves as heavy metal adsorption in Kangkar Senangar's river, Johor. J. Crit. Rev., 7(8): 1415-1420.

Hounsounou EO, Agassounon Djikpo Tchibozo M, Kelome NC, Vissin EW, 
Mensah GA, Agbossou E. 2016. Pollution des eaux à usages domestiques dans les milieux urbains défavorisés des pays en développement: Synthèse bibliographique. Int. J. Biol. Chem. Sci., 10(5): 2392-2412. DOI: http://dx.doi.org/10.4314/ijbcs.v10i5.3

Kayaga S, Reed B. 2009. Technical Notes on Drinking-Water, Sanitation and Hygiene in Emergencies: Emergency Treatment of Drinking Water at the Point of Use. World Health Organization (WHO): Geneva.

Kouakou E. 2007. Étude de la nitrification partielle d'eaux ammoniacales dans un bioréacteur membranaire. Thèse de Doctorat, Université de Liège, Liège, 233 p.

Langenbach KMW. 2009. Slow sand filtration of secondary effluent for wastewater reuse: evaluation of performance and modeling of bacteria removal. $\mathrm{PhD}$ Thesis, Technical University, Munich, $117 \mathrm{p}$.

Neyman KO, Bray R. 2000. The role of physico-chemical and biological processes in manganese and ammonia nitrogen removal from ground water. Pol. J. Environ. Stud., 9(2): 91-96. DOI: http://www.pjoes.com

Rolland L, Molle P, Lienard A, Bouteldja F, Grasmick A. 2009. Influence of the physical and mechanical characteristics of sands on the hydraulic and biological behaviors of sand filters. Desalination, 248(1-3): 998-1007. DOI: https://doi.org/10.1016/j.desal.2008.10.0 16

StatSoft Inc. 2005. STATISTICA for windows version 7.1. Data analysis software system. http://www.statsoft.com.
Strauss EA, Mitchell NL, Lamberti GA. 2002. Factors regulating nitrification in aquatic sediments: effects of organic carbon, nitrogen availability and $\mathrm{pH}$. Canadian $J$. Fish. Aquat. Sci., 59(3): 554-563. DOI: 10.1139/f02-032

Tchobanoglous G, Burton FL, Stensel HD. 2003. Wastewater Engineering: Treatment Disposal and Reuse ( $4^{\text {th }}$ edn). McGraw-Hill: New York.

UNESCO. 2004. Eau, assainissement et développement durable : les enjeux dans les villes des pays en développement. UNESCO, Paris.

Varbanets MP, Zurbrugg C, Swartz C, Pronk W. 2009. Decentralized systems for potable water and the potential of membrane technology. Water Res., 43: 245-265.

DOI: 10.1016/j.watres.2008.10.030

Viccione G, Evangelista S, Marinis GD. 2018. Experimental analysis of the hydraulic performance of wire-wound filter cartridges in domestic plants. Water, 10(309): $1-15 . \quad$ DOI: 10.3390/w10030309

WHO. 2004. Water Treatment and Pathogen Control: Process Efficiency in Achieving Safe Drinking Water (ed). IWA Publishing: London.

WHO. 2008. Guidelines for Drinking-water Quality: Incorporating the First and Second Addenda ( $3^{\text {rd }}$ edn). WHO: Geneva.

Wotton RS. 2002. Water purification using sand. Hydrobiologia, 469(1): 193-201. DOI: 10.1023/A:1015503005899

Zielińska M, Wojnowska BI. 2007. Nitrification by biomass immobilized in porous carriers. J. Environ. Eng. Sci., 6(4): $\quad 463-467 . \quad$ DOI: https://doi.org/10.1139/s06-065 